Research Article

\title{
Study on incidence of congenital anomalies in a rural teaching hospital, Telangana, India
}

\author{
Jayalakshmi Pabbati*, Preethi Subramanian, Sudharshan Raj C., Sadhana N., Raghava Rao
}

Department of Pediatrics, Mediciti Institute of Medical Sciences, Telangana, India

Received: 29 March 2016

Accepted: 09 May 2016

*Correspondence:

Dr. Jayalakshmi Pabbati,

E-mail: drpjlakshmi@gmail.com

Copyright: ( ) the author(s), publisher and licensee Medip Academy. This is an open-access article distributed under the terms of the Creative Commons Attribution Non-Commercial License, which permits unrestricted non-commercial use, distribution, and reproduction in any medium, provided the original work is properly cited.

\section{ABSTRACT}

Background: Congenital anomalies (CA) include abnormalities in the new born baby's structure, function or body metabolism which usually lead to physical and mental disabilities and can even be fatal sometimes. The purpose of the study is to find out overall incidence of congenital malformation and to identify the high risk groups.

Methods: A Longitudinal study was done on 4628 neonates in the Department of Obstetrics and Gynecology and Pediatrics in Mediciti Institute of Medical Sciences, Ghanpur, Hyderabad. All babies born (live and still born) were examined; anomalies documented in a pre-designed proforma within $24 \mathrm{hrs}$ of birth and were further followed for $72 \mathrm{hrs}$. Only visible congenital anomalies (CA) were noted in still born neonates. Relevant maternal and family history was also noted. Whenever required, X-rays, ultrasonography and echocardiography of the newborn were performed.

Results: The overall incidence of CA was $4.08 \%$. The most common system involved is the musculoskeletal system $(37.6 \%)$ followed by central nervous system $(22.75 \%)$. Among the fetal factors, prematurity, stillbirth and low birth weight were significantly associated with high incidence of CA $(\mathrm{p}<0.01)$. Higher risk of anomalies were observed in babies of multiparous (>3 gestation) mothers ( $7.6 \%$ vs $3.96 \%$ ), mothers with bad obstetric history $(5.3 \%$ vs $4.04 \%)$ and with diabetes $(5.5 \%$ vs $4.06 \%)$.

Conclusions: This study brings to light the burden of CA and relevant risk factors in a rural setting which is likely to emerge as one of the leading causes of morbidity \& mortality in the future.

Keywords: Congenital anomalies, Musculoskeletal system, Risk factors, Born

\section{INTRODUCTION}

CA also known as birth defects, congenital disorders or congenital malformations, can be defined as structural or functional anomalies (e.g. metabolic disorders) that occur during intrauterine life and can be identified prenatally, at birth or later in life. ${ }^{1}$

Although approximately $50 \%$ of all CA cannot be linked to a specific cause, there are some known causes or risk factors like single gene defects, chromosomal disorders, environmental chemicals, maternal infections such as rubella, maternal illnesses like diabetes mellitus (DM), iodine and folic acid deficiency and exposure to medicinal and recreational drugs including alcohol, tobacco and radiation. ${ }^{1}$
It is estimated that about $94 \%$ of severe CA occur in lowand middle-income countries. ${ }^{1} \mathrm{CA}$ account for $8-15 \%$ of perinatal deaths and $13-16 \%$ of neonatal deaths in India. ${ }^{2}$ The proportion of perinatal deaths due to $\mathrm{CA}$ is increasing as a result of reduction in mortality from other causes secondary to a gradual improvement in the management of prematurity, asphyxia and sepsis through tertiary care newborn units across the country. Birth defects in the coming decades are likely to emerge as a major cause of morbidity and mortality.,4

Hence it is important to do epidemiologic surveys of CA in various parts of the world with different environment, socioeconomic status and ethnic groups with widely varying marital habits. Most of the studies on CA are hospital based studies and represent mainly the urban or 
semi urban population. Little information is available on incidence of $\mathrm{CA}$ from rural population.

This study was carried out with an aim to determine the overall incidence of CA in live births and stillbirths, as well as incidence affecting various organ systems and to identify groups at risk for higher incidence of $\mathrm{CA}$ in a rural population.

\section{METHODS}

A Longitudinal study was done for a duration of two years i.e., from November 2012 to Oct 2014. A total of 4628 babies born (live and still born) in the Department of Obstetrics and Gynecology, Mediciti Institute of Medical Sciences, Ghanpur, Hyderabad were enrolled after approval from the institution's ethical committee. An informed consent was taken from parents. Baby's gestational age, birth weight, birth order, sex, consanguinity and relevant maternal and family history were noted in a pre-designed proforma.

The detailed general and systemic examinations of the babies were carried out within $24 \mathrm{hrs}$ of birth and only visible anomalies were noted in stillborn by two pediatricians separately for each baby. All live born babies were further followed for $72 \mathrm{hrs}$. The newborn babies who required intensive care were shifted to NICU of same institute.

Ultrasound abdomen, 2D-Echo, neurosonogram and $\mathrm{x}$ rays were done to detect internal anomalies. CT/ MRI brain were done whenever required. Anomalies were divided into central nervous system (CNS), musculoskeletal, gastrointestinal, genitourinary, cardiovascular system (CVS), and miscellaneous disorders. Statistical analysis was done using Chi-square test.

\section{RESULTS}

Table 1: Distribution of anomalies in live born and stillborn neonates.

\begin{tabular}{|llll|}
\hline & $\begin{array}{l}\text { Total No. of } \\
\text { babies }\end{array}$ & $\begin{array}{l}\text { Malformed } \\
\text { babies }\end{array}$ & $\%$ \\
\hline Live births & 4563 & 177 & 3.87 \\
\hline Still births & 65 & 12 & 18.46 \\
\hline Total & 4628 & 189 & 4.08 \\
\hline
\end{tabular}

Total number of neonates included in this study was 4628, live births were 4563 and stillbirths were 65 . Total number of anomalous babies was 189 (177 live born and 12 stillborn). The overall incidence of CA was found to be $4.08 \%$. CA were seen more significantly in stillbirths ( $\mathrm{P}<0.01)$ as compared to live births, the frequency being $18.46 \%$ and $3.87 \%$ respectively as observed in Table 1.
The sex wise distribution of CA in live born babies was $3.76 \%$ in males and $4 \%$ in females. In stillborn babies with CA, males constituted $21.4 \%$ and females constituted $13 \%$. The difference between anomalous male and female neonates in both live born and stillborn categories was not statistically significant.

Table 2: Distribution of anomalies among term and preterm neonates.

\begin{tabular}{|llll|}
\hline & Term (\%) & Preterm (\%) & Total \\
\hline $\begin{array}{l}\text { CA- } \\
\text { Present }\end{array}$ & $56(1.86)$ & $133(8.2)$ & 189 \\
\hline CA-Absent & $2952(98.14)$ & $1487(91.8)$ & 4439 \\
\hline Total & 3008 & 1620 & 4628 \\
\hline
\end{tabular}

According to the gestational age, among 1620 preterm babies, anomalous babies were about 133 which constituted about 8.2\% (Table 2). Among 3008 term babies, anomalous babies were about 56 which constitute about $1.86 \%$. The incidence of CA was more in preterm neonates than in term babies. $(\mathrm{P}<0.01)$

Table 3: Distribution of anomalies in low and normal birth weight babies.

\begin{tabular}{|llll|}
\hline & $\begin{array}{l}\text { Normal } \\
\text { birth weight } \\
(\%)\end{array}$ & $\begin{array}{l}\text { Low birth } \\
\text { weight }(\%)\end{array}$ & Total \\
\hline $\begin{array}{l}\text { CA- } \\
\text { Present }\end{array}$ & $42(1.9)$ & $147(6.07)$ & 189 \\
\hline CA-Absent & $2166(98.1)$ & $2273(93.93)$ & 4439 \\
\hline Total & 2208 & 2420 & 4628 \\
\hline
\end{tabular}

Table 4: Distribution of system wise congenital anomalies $(\mathrm{N}=189)$.

\begin{tabular}{|llll|}
\hline System & $\begin{array}{l}\text { No of } \\
\text { babies } \\
\text { with } \\
\text { congenital } \\
\text { anomalies }\end{array}$ & $\%$ & $\begin{array}{l}\text { Incidence/1000 } \\
\text { births }\end{array}$ \\
\hline Musculoskeletal & 71 & 37.6 & $15.34 / 1000$ \\
\hline $\begin{array}{l}\text { Central nervous } \\
\text { System }\end{array}$ & 43 & 22.7 & $9.29 / 1000$ \\
\hline Cardiovascular & 36 & 19.0 & $7.78 / 1000$ \\
\hline $\begin{array}{l}\text { Genitourinary } \\
\text { tract }\end{array}$ & 21 & 11.1 & $4.54 / 1000$ \\
\hline Gastrointestinal & 10 & 5.3 & $2.16 / 1000$ \\
\hline Miscellaneous & 5 & 2.7 & $1.08 / 1000$ \\
\hline Multiple & 3 & 1.6 & $0.64 / 1000$ \\
\hline Total & 189 & 100 & \\
\hline
\end{tabular}

According to the birth weight, the total number of low birth weight babies was 2420; anomalous babies were 147 constituting about $6.07 \%$. Among the babies with weight $\geq 2.5 \mathrm{~kg}$ (2208), anomalous babies were about 42 constituting $1.9 \%$ (Table 3 ). The incidence of CA was 
more in low birth weight babies than in babies with normal birth weight $(\mathrm{P}<0.01)$.

The most common organ system involved was the musculoskeletal system $(37.6 \%)$ followed by central nervous system $(22.7 \%)$ and cardiovascular system $(19 \%)$ in this study. The distribution of anomalies in other systems is as depicted in Table 4.

Table 5: Congenital anomalies in relation to maternal factors.

\begin{tabular}{|c|c|c|c|}
\hline Factors & $\begin{array}{l}\text { Total } \\
\text { number of } \\
\text { babies }\end{array}$ & $\begin{array}{l}\text { Number of } \\
\text { anomalous } \\
\text { births }\end{array}$ & $\%$ \\
\hline \multicolumn{4}{|c|}{ Maternal age } \\
\hline$<30 \mathrm{yr}$ & 4413 & 185 & 4.19 \\
\hline$>30 \mathrm{yr}$ & 215 & 4 & 1.86 \\
\hline \multicolumn{4}{|l|}{ Gravida } \\
\hline 3 or less & 4484 & 178 & 3.96 \\
\hline$>3$ & 144 & 11 & 7.6 \\
\hline \multicolumn{4}{|c|}{ Bad obstetric history } \\
\hline Yes & 130 & 7 & 5.3 \\
\hline No & 4498 & 182 & 4.04 \\
\hline \multicolumn{4}{|l|}{ Anemia } \\
\hline Yes & 568 & 8 & 1.41 \\
\hline No & 4060 & 181 & 4.46 \\
\hline \multicolumn{4}{|l|}{ Diabetes } \\
\hline Yes & 54 & 3 & 5.5 \\
\hline No & 4574 & 186 & 4.06 \\
\hline \multicolumn{4}{|c|}{ Pre-eclampsia and Eclampsia } \\
\hline Yes & 164 & 3 & 1.8 \\
\hline No & 4464 & 186 & 4.1 \\
\hline
\end{tabular}

The various maternal factors in relation to congenital anomalies are described in Table 5.With respect to maternal factors incidence of $\mathrm{CA}$ was more in multiparous mothers $(7.6 \%)$, mothers with bad obstetric history $(5.3 \%)$ and with diabetes mellitus (5.5\%).

\section{DISCUSSION}

CA (also referred as birth defects) affect approximately 1 in 33 infants and result in approximately 3.2 million birth defect-related disabilities every year. ${ }^{5}$ An estimated 270 000 newborns die during the first 28 days of life every year from CA. Worldwide, the incidence of CA varies between geographical regions but it is estimated that 3 $7 \%$ of children are born with birth defects. ${ }^{6}$ The birth prevalence of $\mathrm{CA}$ in the developing world is underestimated by deficiencies in diagnostic capabilities and lack of reliability of medical records and health statistics. $^{7}$

The World Health Assembly at their 2010 meeting passed a resolution urging member states to raise awareness about the importance of birth defects as the cause of child morbidity and mortality. ${ }^{8} \mathrm{CA}$ may result in long-term disability, which may have significant impacts on individuals, families, health-care systems and societies.
This study showed incidence of congenital anomalies as $4.08 \%$ (189/4628) of consecutive births which correlates with previous studies. ${ }^{9-12}$ Present study showed higher incidence of CA in stillborn babies (18.46\%) consistent with previous study. ${ }^{13}$

In the present study, sex of the baby had no significant association with development of CA. ${ }^{14}$ The incidence of $\mathrm{CA}$ in present study was significantly higher in pre-term babies. It represented the phenomenon of Nature's Selection and was consistent with results of previous articles. ${ }^{2,13}$ Association of LBW with increased incidence of anomalies was found in present study and was in accordance with results of previous studies. ${ }^{13,14}$

In the present study with regard to pattern of CA, the most common system involved is Musculoskeletal system (37.6\%) followed by central nervous system (22.7\%), cardiovascular (19\%), genitourinary (11.1\%), gastrointestinal $(5.3 \%)$ and miscellaneous $(2.7 \%)$. Anomalies of multiple organ systems were found in 3 babies (1.6\%). El Koumi MA et al, Sarkar et al and Singh A et al also found high incidence of musculoskeletal system anomalies. ${ }^{14-16}$

Most common anomaly is Talipes followed by cleft lip and palate in our study. Higher risk of anomalies were observed in babies of multiparous ( $>3$ gestation) mothers (7.6\% vs $3.96 \%)$, mothers with bad obstetric history (5.3\% vs $4.04 \%)$ and with diabetes (5.5\% vs $4.06 \%)$ in our study.

The annual report of Indian Council of Medical Research says that the commonest $\mathrm{CA}$ are cardiac in nature $(0.57 \%) .{ }^{17}$ Cardiovascular anomalies were less in our study which could be due to lack of autopsies in stillborn born babies. The relative difference in the occurrence of various anomalies might be due to geographic and racial difference. True incidence of CA depends on several factors and therefore two studies are never strictly comparable.

The incidence of CA can be reduced by following prevention strategies include primary secondary and tertiary levels of prevention. These strategies can be applicable at various stages of pregnancy that is Preconception, Antenatal and Postnatal period. ${ }^{18}$

\section{CONCLUSION}

This study brings out the incidence of congenital anomalies in a rural setting. Musculoskeletal \& Central nervous system anomalies contribute to more than $50 \%$ of them.

\section{ACKNOWLEDGEMENTS}

We would like to acknowledge the contribution of the department of Obstetrics and Gynecology of our institute. 
Funding: No funding sources

Conflict of interest: None declared

Ethical approval: The study was approved by the Institutional Ethics Committee

\section{REFERENCES}

1. WHO. Congenital anomalies. Available From: Fact sheet N370. Updated April 2015. www.who.int/mediacentre/factsheets/fs370/en/.

2. Taksande A, Vilhekar K, Chaturvedi P, Jain M. Congenital malformations at birth in Central India: A rural medical college hospital based data. Indian $\mathrm{J}$ Hum Genet. 2010;16:159-63.

3. Bhat BV, Ravikumara M. Perinatal mortality in India-Need for introspection. Indian J Matern Child Health. 1996;7:31-3.

4. Agarwal SS, Singh U, Singh PS, Singh SS, Das V, Sharma A, et al. Prevalence and spectrum of congenital malformations in a prospective study at a teaching hospital. Indian J Med Res. 1991;94:413-9.

5. Media centre. Congenital anomalies, Fact sheet N³70 October 2012 Available at: http://www.who.int/mediacentre/facts heets/fs370/en/index.html.

6. Sekhobo JP, Druschel CM. An evaluation of congenital malformations surveillance in New York State: an application of centers for disease control and prevention (CDC) guidelines for evaluating surveillance systems. Public Health Rep. 2001;116:296-305.

7. Penchaszadeh VB. Preventing Congenital Anomalies in Developing Countries. Community Genet. 2002;5:61-9.

8. WHO. Birth Defects. Sixty-Third World Health Assembly. Agenda item 11.7. [Internet]. 2012 [cited 2012 Feb]. Available from: http://apps.who.int/gb/ebwha/ pdf_files/WHA63/ A63_R17-en.pdf.

9. Verma IC, Jacob T. Clinical and genetic aspects of malformations of central nervous system. J All India Inst Med Sci. 1976;1:164-8.

10. Clark RD, Eteson DJ. Congenital Anomalies. p.159.

11. Malhotra P, Thapar K. Pattern of Major congenital anomalies and their outcome. IJMDS. 2015;4(1).

12. Hussain S, Asghar I, Sabir M, Chattha MN. Prevalence and pattern of congenital malformations among neonates in the neonatal unit of a teaching hospital. 2014;64(6):629-34.

13. Parmar A, Rathod SP, Patel SV, Patel SM. A Study of Congenital Anomalies in Newborn. National Journal of Integrated Research in Medicine. 2010;1(1).

14. El Koumi MA, Al Banna EA, Lebda I. Pattern of congenital anomalies in newborn: a hospital-based study. Pediatric Reports. 2013;:e5:20-3.

15. Sarkar S, Patra C, Dasgupta MK, Nayek K. Prevalence of Congenital Anomalies in Neonates and Associated Risk Factors in a Tertiary Care Hospital in Eastern India. Journal of Clinical Neonatology. 2013;2(3):131-4.

16. Singh A, Gupta RK. Pattern of Congenital Anomalies in Newborn: A Hospital Based Prospective Study. JK SCIENCE. 2009;11(1).

17. ICMR, New Delhi: Reproductive health; Annual report, 2002-03; p 91.

18. Kar A. Birth Defects in India: Magnitude, Public Health Impact and Prevention. JKIMSU. 2014;3(2).

Cite this article as: Pabbati J, Subramanian $\mathrm{P}$, Sudharshan RC, Sadhana N, Rao R. Study on incidence of congenital anomalies in a rural teaching hospital, Telangana, India. Int J Contemp Pediatr 2016;3:887-90. 